\title{
Contributions of Chemical and Isotopic Tools for Understanding the Groundwater Modes Recharge and Flow in the Lower Cretaceous Aquifer in the Moroccan Sahara
}

\author{
Nabila Edoulati, Said Boutaleb, Ismail Bettar, Ali Ouchbani \\ Laboratory of Applied Geosciences and Geo-Environmental, Ibn Zohr University, Agadir, Morocco \\ Email:nabilaaze@gmail.com
}

Received September 24, 2012; revised November 12, 2012; accepted December 7, 2012

\begin{abstract}
The present work was conducted in the basin of Laayoun-Dakhla (South Morocco) to: 1) identify the recharge and flow characteristics of the Lower Cretaceous aquifer (LC); and 2) provide information about the mineralization of aquifer's water. Isotopic and hydrochemical compositions combined with the geological and hydrogeological settings were used for this purpose. The principal changes in chemical composition of LC groundwater result from mixing with water of deeper circulation. Closer analysis of available chemical data reveals the importance of dissolution/precipitation processes in evolution of groundwater chemistry. Piezometric levels, as well as chemical and isotopic composition of groundwaters, confirm hydraulic connection between the LC and the others aquifers. Overlap of some major characteristics $\left(\delta 180, \delta 2 \mathrm{H}, ~^{-} \mathrm{Cl}^{-}\right)$in this aquifer suggests that mixing processes considerably influence the hydrochemical evolution of water. The surface electrical resistivity does not indicate any freshwater-saltwater interface in the coastal aquifer and the relationship between $18 \mathrm{O}$ and $\mathrm{Cl}$ allows us to reject the hypothesis of a seawater intrusion.
\end{abstract}

Keywords: Lower Cretaceous Aquifer; Arid Area; Process of Mineralization; Seawater Intrusion; Recharge and Flow

\section{Introduction}

In arid regions, overexploitation of groundwater induced alarming declines in water levels. The groundwater management of such regions passes first through an understanding and delimitation of recharge areas and their hydrodynamic behavior. For this aim, several techniques are used, including the hydrochemical and isotopic tools $[1,2]$; those will be used in this study; applied to the lower Cretaceous aquifer (LC) of southern Morocco.

The choice of this aquifer is based on the facts that it is the only aquifer in the area intensively exploited and is the most important by its extension across the basin of Laayoune-Dakhla (about 90,000 $\mathrm{km}^{2}$ ) and productivity (up to $70 \mathrm{l} / \mathrm{s} /$ well).

The basin of the Laayoun-Dakhla is now, more than ever, faces multiple constraints [3]:

- Overexploitation of groundwater (the global flow equipped for drinking water is $245 \mathrm{l} / \mathrm{s}$;

- Increasing urbanization $(82 \%$ of the total population of the study area;

- Emergence of new water needs and (agriculture, breeding, sea fishing and mines...);

- Continued degradation of the surface waters quality (solid waste is disposed to public dumps located generally within $15 \mathrm{~km}$ of Commons, in trays, bowls or careers).

The systematic use of underground water reserves (LC) become a necessity. The good management of this aquifer can extended the viability of the resource in this area where the recharge is not sufficient in front of the demand of the water supply.

In the presented study, hydrogeological, hydrochemical and isotopic information from the groundwater system is integrated and used to determine the main factors and mechanisms controlling the chemistry of LC aquifer in the investigated area. Geochemical data are particularly useful for evaluating groundwater evolution and recharge in the arid regions of North Africa (Sahara Algerien [4], arid zone Morocco [5], Tunisie [6], NWLibya [7], Egypt [8]...). The main issues that will be addressed in this paper include: 1) processes affecting salinization of groundwater; 2) relative importance of hydrological and geological factors controlling water chemistry; 3) location of recharge zones, and 4) identification of hydraulic interconnection between the aquifer systems. 


\section{Study Area}

The sedimentary basin of Laayoune-Dakhla $\left(17^{\circ} \mathrm{E}-11^{\circ} \mathrm{E}\right.$, $20^{\circ} 40^{\prime} \mathrm{N}-28^{\circ} 48^{\prime} \mathrm{N}$ ), situated in southern Morocco, covers an area about $326,810 \mathrm{~km}^{2}$. It is presented in tabular plains which stretch from north to south along the Atlantic Ocean with a width up to $400 \mathrm{~km}$ and altitudes ranged between 0 to $400 \mathrm{~m}$. The basin is bordered in the west by the Atlantic Ocean and southeast by the fault of Zemmour which separate the older African massif, such as Anti-Atlas chain, the Mauritanides chain and the Tindouf Basin. It contains significant groundwater resources circulating in a complex aquifer consisting of shallow and deep aquifers (Figure 1). In this basin three aquifers are known:

- Plio-Quaternary formations containing alluvial aquifers, such as the water layer of Laayoune and the Foum El Oued aquifer;

- The Paleogene aquifer consists of marly sands; it's generally encountered at depths ranging between 150 and $300 \mathrm{~m}$;

- The Lower Cretaceous aquifer containing waters in sandstones, marly limestone and shows a great variability in lithology. It is the largest one in the Sahara basin by its extension and its lithology that allowed a considerable supply of groundwater.

\section{Climate}

Southern Morocco is characterized by an arid climate. The annual precipitation is low $(59 \mathrm{~mm}$ in the North at laâyoune station, $30 \mathrm{~mm}$ in the south at Dakhla station and $22 \mathrm{~mm}$ in Smara in the Est) and irregular. The annual average temperature varies between $17^{\circ} \mathrm{C}$ on the coast (Laâyoune) and $25^{\circ} \mathrm{C}$ elsewhere (Smara). The maximum and minimum values are respectively about $40^{\circ} \mathrm{C}(\mathrm{Au}-$ gust) and $10^{\circ} \mathrm{C}$ (January). The monthly average evaporation registered a maximum value in Laayoune station of about $183 \mathrm{~mm}$ in August which is the hottest month of the year and a minimum value of about $133 \mathrm{~mm}$ in December. The monthly average value $(159 \mathrm{~mm})$ is usually over than the monthly average rainfall $(4.96 \mathrm{~mm})$ Registered in the same period (1993-2011).

\section{Geology}

The regional geology has been discussed by several authors since 1934 especially in the Tarfaya basin [9-11] The summary of these studies shows that in the North part of the basin, after a phase of emersion in the late Jurassic, a thick sequence of continental to marine deltaic (formation of Tan Tan) is deposited in the basin during the Neocomian. The thickness of the Barremian formation, characterized by a sandy lagoon facies varies widely from $550 \mathrm{~m}$ (900/120 drilling) to $1345 \mathrm{~m}$ (Puerto Can- sado drilling) [11]. A representative NW-SE cross section linking Gueltat Zemmour (SE) to Laâyoune (NW) (Figure 2) shows an embedding of regular sedimentary interfaces from East to West. Easterly, the formation of Lower Cretaceous is beveled towards Gueltat Zemmour approaching Infra-Cambrian and Primary outcrops. The substratum consisting of primary quartzite is encountered at $105 \mathrm{~m}$ in deep by drilling $97 / 124$. On these primary formations, were deposited a Lower Cretaceous series which are represented by sands interbedded with clay. The roof of this sand is reached at $625 \mathrm{~m}$ deep at the oil drilling (UTAH A2-41). Beyond this drilling, the roof of white sand and red clay rises roughly and is located only at $117 \mathrm{~m}$ of depth in Aoulitis drilling (95/124), and to 22 $m$ in 97/124. This rise in the roof of 1) the Lower Cretaceous; 2) the Triassic formations; and 3) the Jurassic formations, is due to a normal fault or a large flexure found in the north region of Sidi Khattari and even further north between oil drilling D2-9 and A1-10 [12]. In the west and in the coastal zone, the Lower Cretaceous becomes deep and clayey. The depth of the sands roof reach from $625 \mathrm{~m}$ in oil drilling (UETAT A2-41) to $850 \mathrm{~m}$ in deep drilling of Boucraâ (650/120), more than $1800 \mathrm{~m}$ in Boujdour region. Only the drilling 110/124 (Jreifia-2) achieves the sands of LC at $746 \mathrm{~m}$. However, it is the series of Oligocene (formed of chalky clay-micrite, and dolomitic sandstone clay) and of Middle and Late Miocene (formed of red sandstone and plastic clays interbedded with sands) that have developed in this region. It's due probably to a tectonic activity; characterized by rift fault; more pronounced in west than in east during the LC $[11,15,16]$.

In the south part of the basin, the analysis of drilling logs indicates a regular embedding sedimentary series from SE to NW reflecting Monocline structure (Figure 3). A thick series of clastic Lower Cretaceous, represented by sands interbedded with clay, based unconformably on a Precambrian metamorphic substratum recognized by a drilling E1-66 at $1613 \mathrm{~m}$ of depht. The roof of the sand is at $252 \mathrm{~m}$ in E1-66 drilling, while it outcrops at $2 \mathrm{~km}$ further east in the region of El Fouch. This roof has been reached by deep drilling of Gleib Jediane $\mathrm{N}^{\circ}$ IRE $128 / 125$ at $443 \mathrm{~m}$ and that of Laârgoub at $500 \mathrm{~m}$ of depth. At Dakhla, no drilling has reached the roof of the Lower Cretaceous; reaching depths estimated locally over $600 \mathrm{~m}$.

\section{Structural Framework and Piezometry}

Three structural directions (Faults and folds) are observed in the Moroccan Sahara basin by [10]:

- NNE-SSW direction, equivalent to the major Meseta direction.

- WSW-ENE, equivalent to the Atlas direction. 


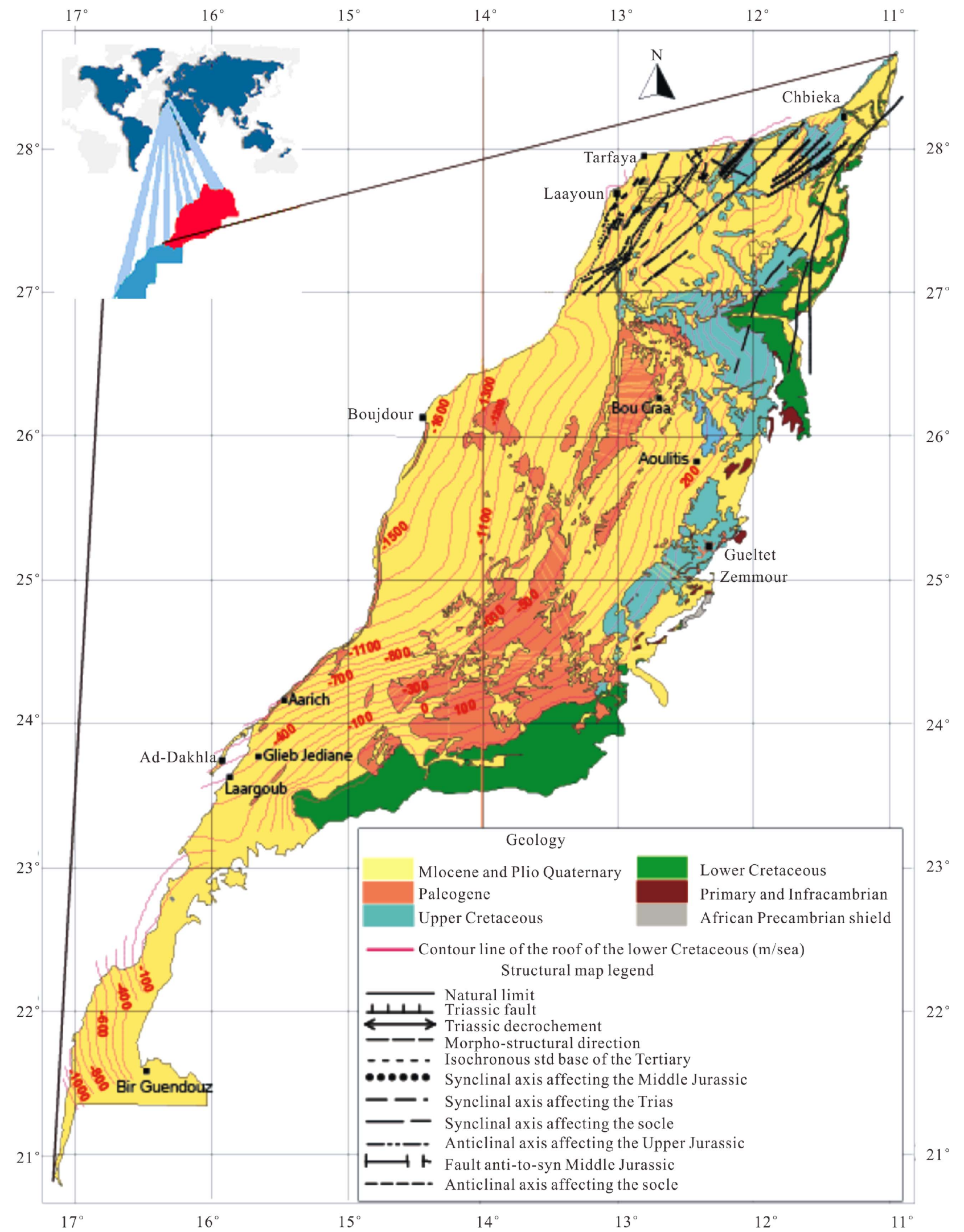

Figure 1. Geological Map of the study area showing the roof of the Lower Cretaceous formations and structure of the northern basin Laayoune-Dakhla [3]. 


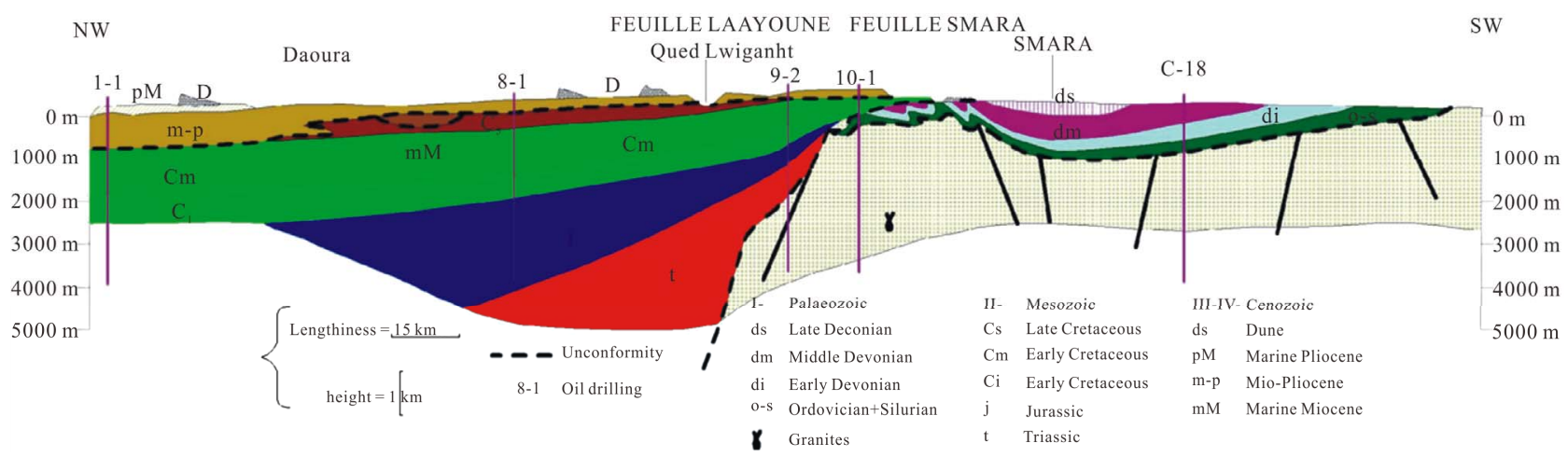

Figure 2. Geological section in the basin of Laayoune-Dakhla (1988) [3].

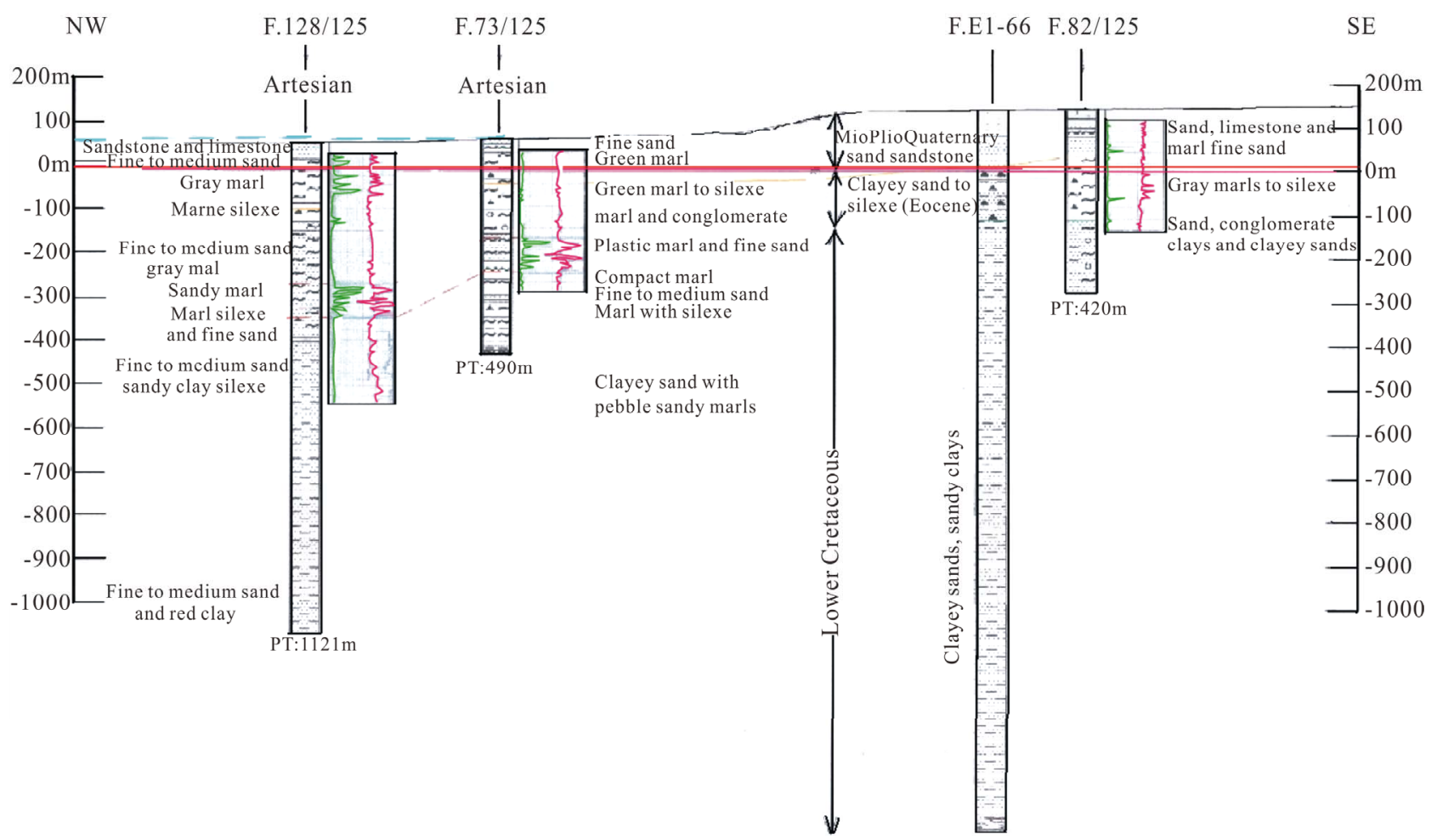

Figure 3. Corresponding cut logs along the radioactive and resistant passage in direction NW-SE [3].

- NW-SE roughly N-S, equivalent to the ougartienne direction. This direction is very evident in the Precabrian outcrops in the south region where the sedimentary cover is thin. Tectonic activity and changes in facies and in thickness of sedimentary deposits seem to play an important role in groundwater flow and hydraulic continuity. The thickening of the units and lithological changes had an important influence on piezometry levels and chemical composition of water. The groundwater level decreases from $200 \mathrm{~m}$ in the East to a few meters to the West. The general groundwater flow directions (Figure 4) are from the East to the West with a high hydraulic gradient in the North basin. In the South part of the basin, the water flows a NE-SW direction and isopiezes have values ranging between 40 and $60 \mathrm{~m} / \mathrm{sea}$ in the region of $\mathrm{Ed}$ Dakhla, behind artesianism phenomena observed in this sector.

\section{Sampling and Analytical Methods}

69 groundwater samples from the LC aquifer were collected during January-Februry 2011 from pumping wells and drilling. Several analyses such as the water temperature, $\mathrm{pH}$ and electrical conductivity (EC) were carried out on-site. Chemical analyses were performed at the Laboratory of Applied Geology and Geo-Environmental University of Agadir. Samples revealing relatively high salinity (exceeding $3 \mathrm{~g} / \mathrm{l}$ ) were diluted before analysis. The isotopic data used for our study are collected from avail- 


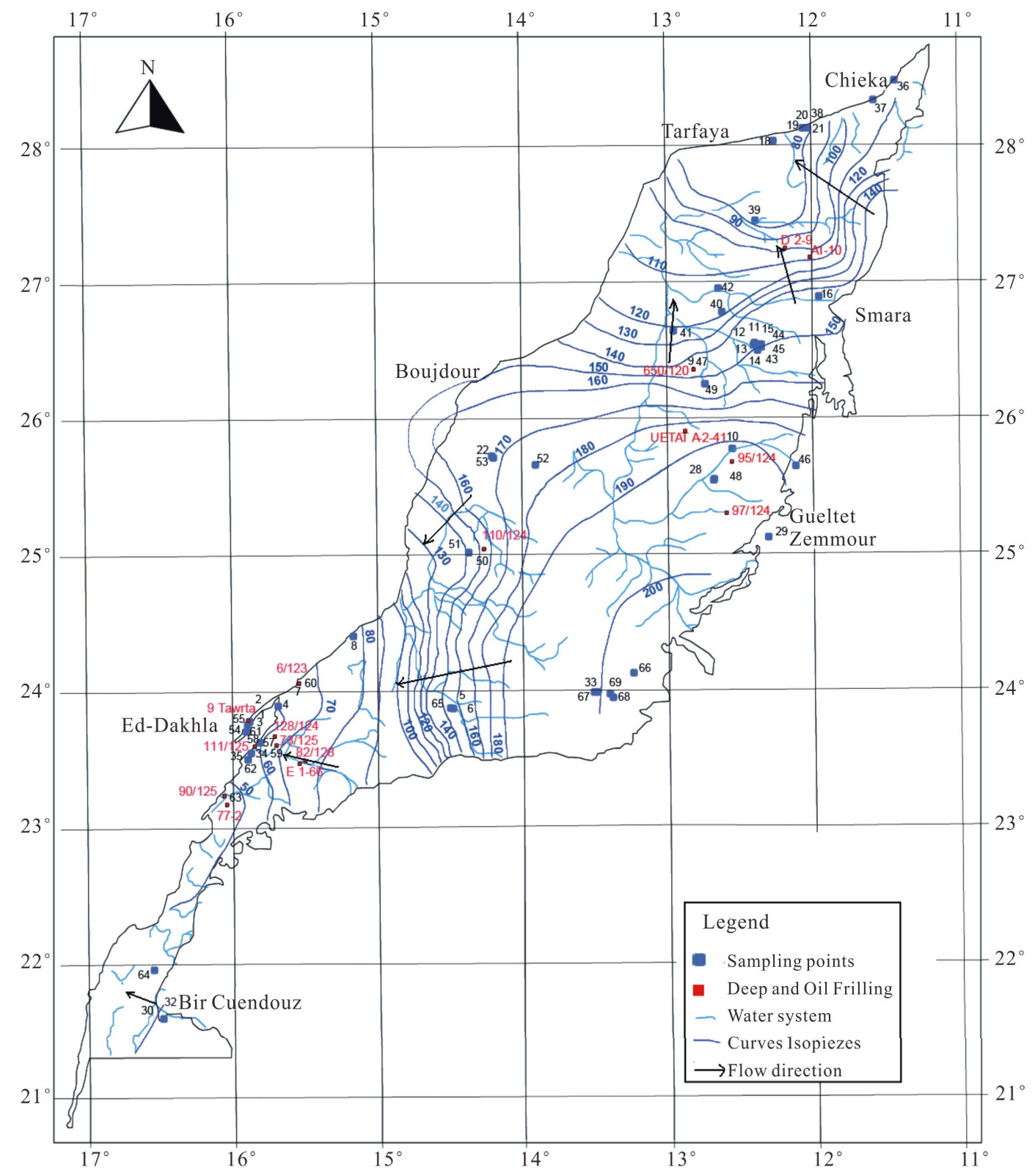

Figure 4. Isopieze lines of the deep Cretaceous groundwater (2005).

able dataset of the "Hydraulic Basin Agency of Sakia El-Hamra and Oued Ed-Dahab".

\section{Results and Discussion}

\subsection{Chemistry of Groundwater}

Most groundwater samples originating from the LC aquifer are characterized by a high total mineralization, with EC ranging from $668 \mu \mathrm{s} / \mathrm{cm}$ in borehole $\mathrm{N}^{\circ} 32$ located at the SW of the basin to $27,304 \mu \mathrm{s} / \mathrm{cm}$ in drilling $\mathrm{N}^{\circ} 38$ located NW of the study area and 49,040 $\mu \mathrm{s} / \mathrm{cm}$ in the west $\left(\mathrm{N}^{\circ} 53\right)$. This variation is well represented on the map of the conductivity (Figure 5). The waters have temperatures between $21.59^{\circ} \mathrm{C}\left(\mathrm{N}^{\circ} 2\right)$ and $61^{\circ} \mathrm{C}\left(\mathrm{N}^{\circ} 22\right.$ and
$\mathrm{N}^{\circ} 53$ ). The high temperature values characterize mainly the waters of the coastal deeper confined aquifer (Figure 5). They are classified as meso-thermal-waters that include waters whose temperatures are more than $30^{\circ} \mathrm{C}$. The proportions between main cations and anions are presented in the form of a Piper diagram [17] (Figure 6). The northern and western groundwater samples reveal a sulfated-sodium and chloride-sodium types, with a tendency to the calcium pole. Otherwise, the bicarbonatesodic and bicarbonate-calcic types are dominant in the south East of the aquifer.

Correlations established between the concentrations of each major component and the electrical conductivity of groundwater are used to determine the chemical elements 

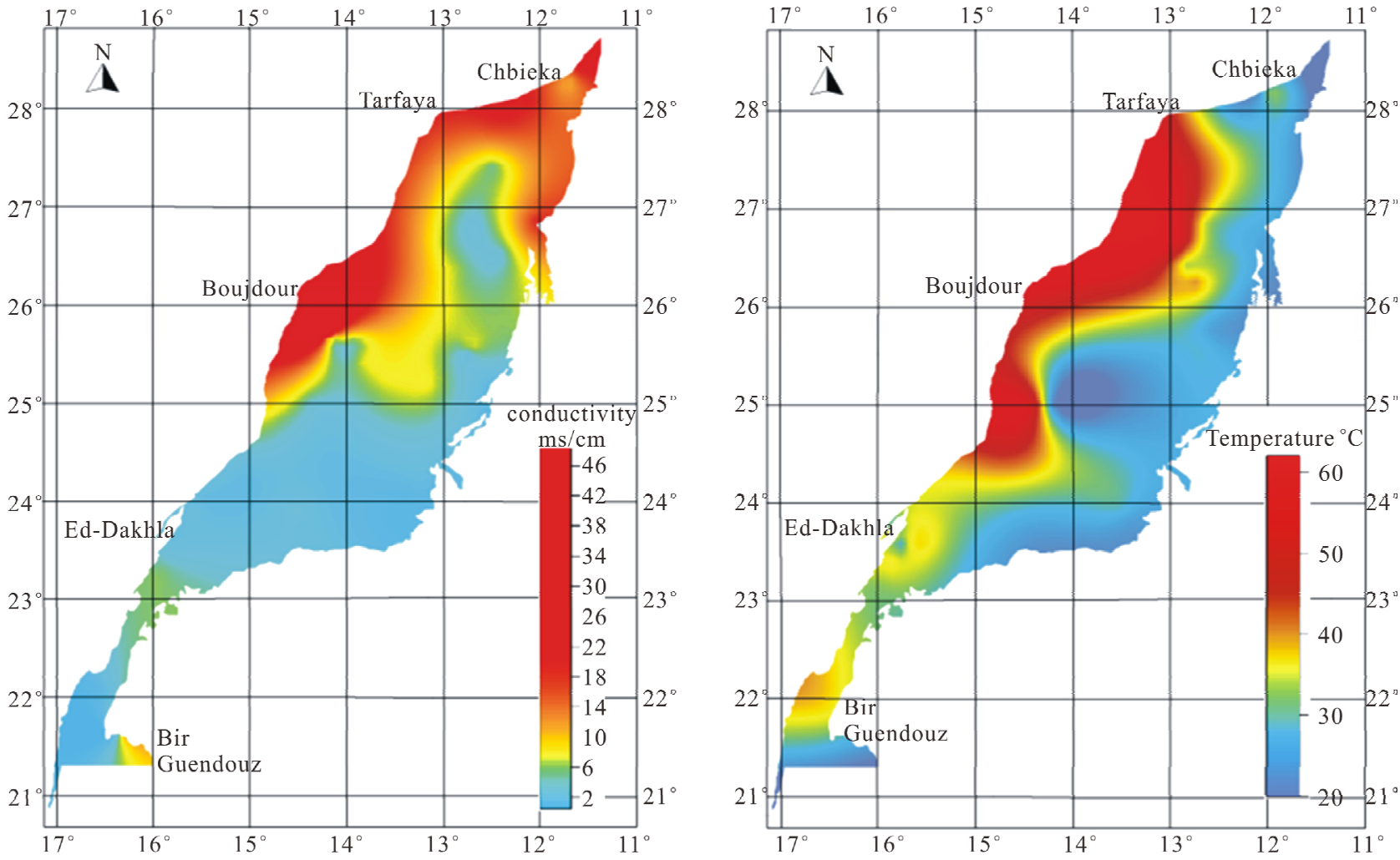

Figure 5. Spatial distribution map of conductivity and temperature.

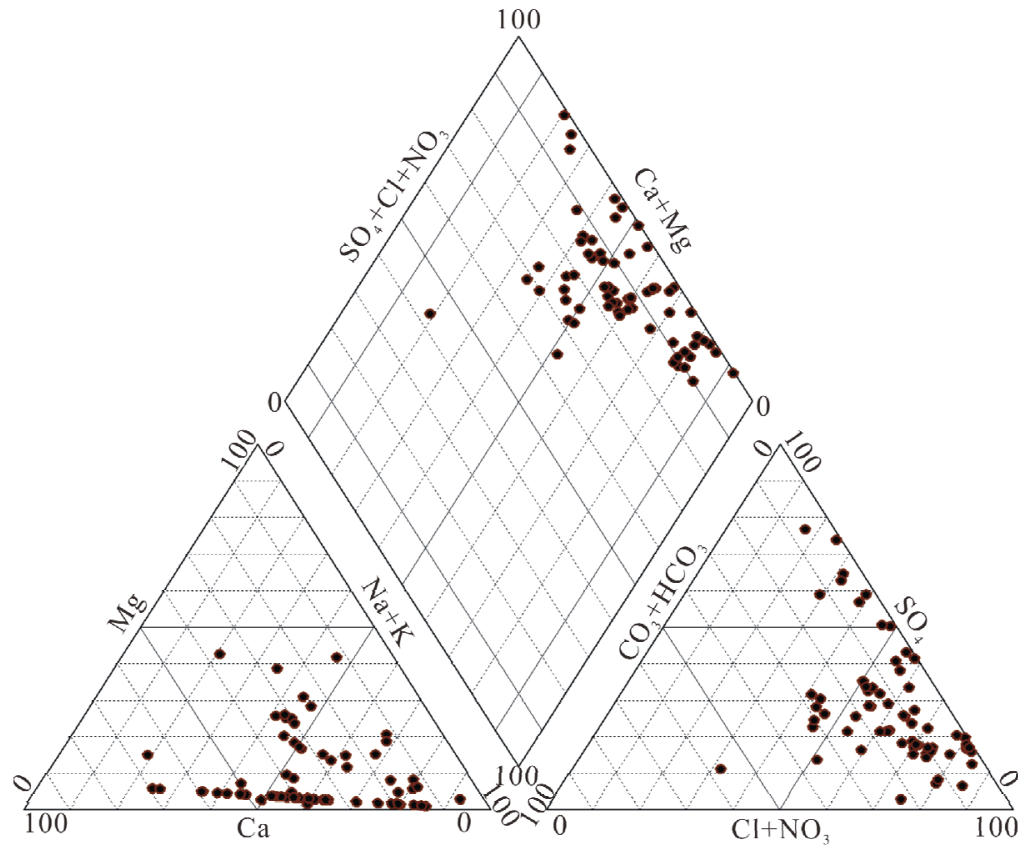

Figure 6. Piper diagram of the Lower Cretaceous groundwater sample.

responsible of this mineralization (Figure 7). In general, the concentrations of sodium, chloride and sulfate are well correlated with the conductivity; the correlation coefficients are respectively $0.67,0.86$ and 0.55 . The analysis of correlations between the $\mathrm{Ca}, \mathrm{Mg}, \mathrm{K}, \mathrm{HCO}_{3}$ and the conductivity show that the points are dispersed in relation to the lines of correlation in graphics. They are weakly correlate as evidenced by the low values of the 

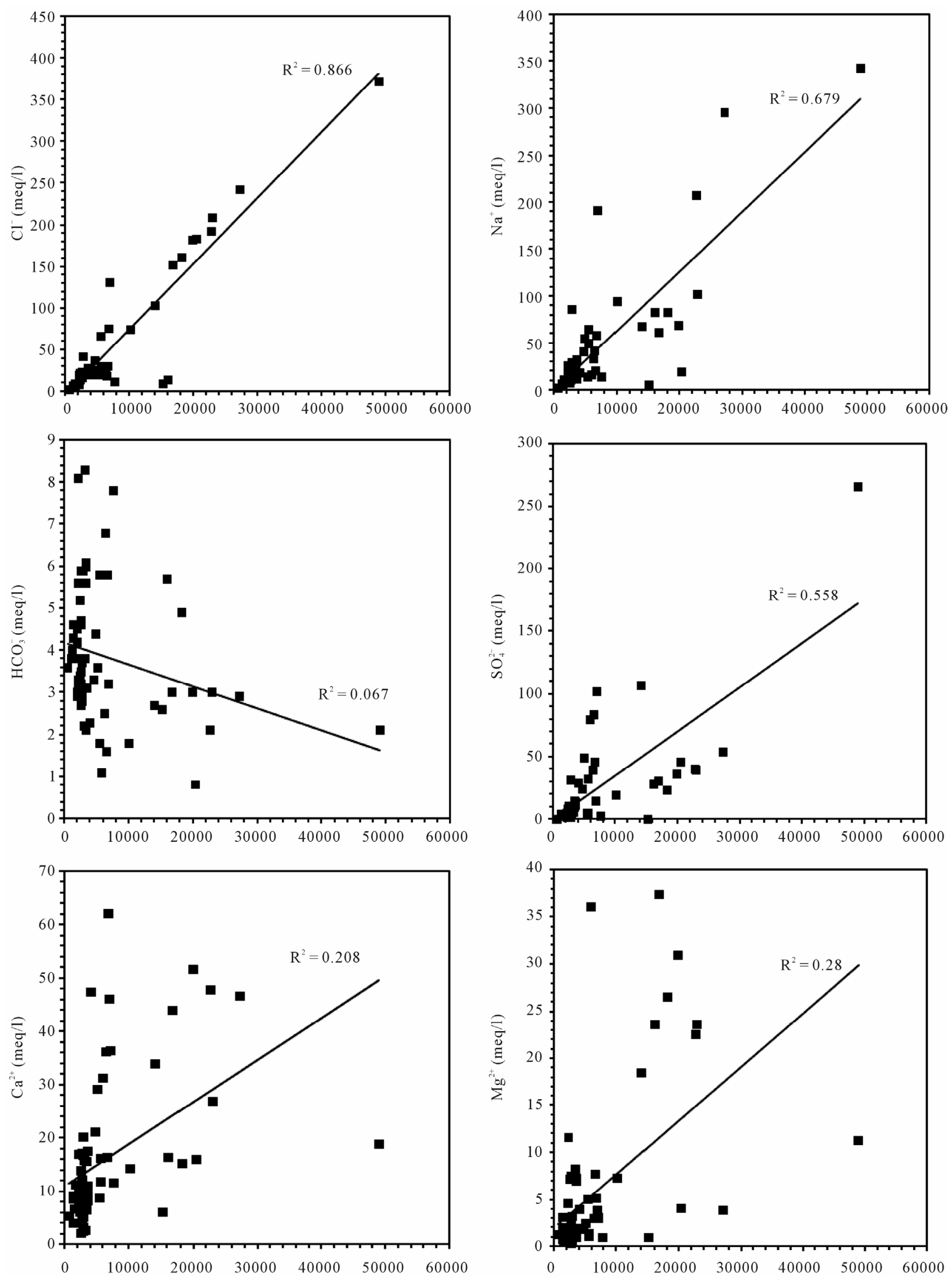


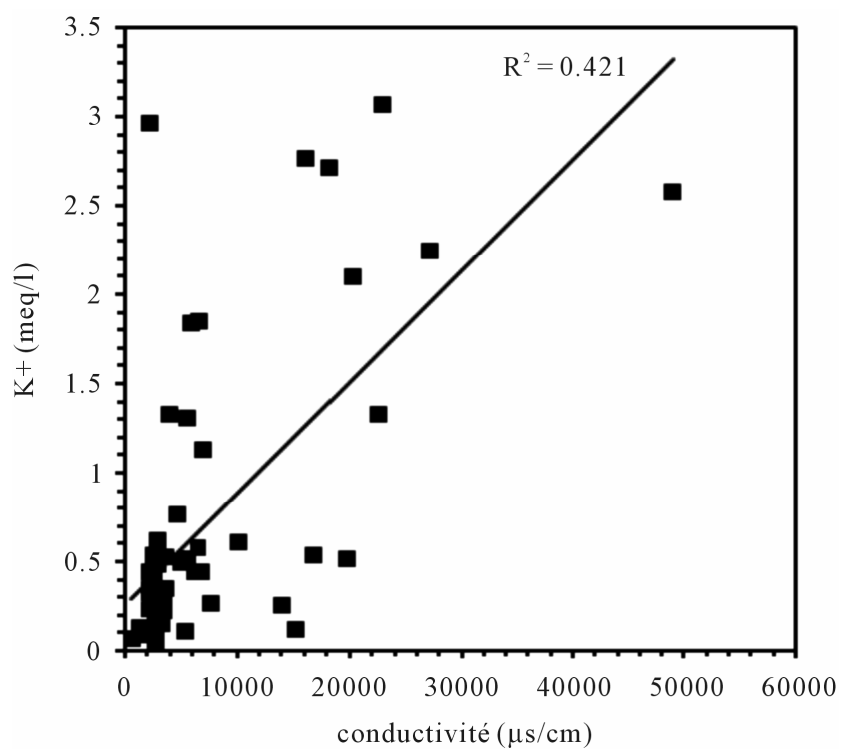

Figure 7. Correlation between diferents major elements with the conductivity.

correlation coefficients of $0.2,0.28,0.42$ and 0.06 .

\subsection{The Spatial Variation of the Mineralization}

An analysis of spatial distribution of chemical parameters shows a large space variation of mineralization from north to south, and an increasing evolution of mineralization to the West is disturbed in the northern zone (Figure 8).

The spatial distribution of chemical elements shows a perfect correlation between the distribution of chlorides, sulfates, magnesium and sodium which coincides with the conductivity distribution. The highest concentrations of elements responsible for the mineralization are recorded mainly in the northern basin, while the central and southern parts are characterized by low values of these elements. The high concentration of bicarbonates is recorded in the South East of the basin.

The position analysis of high salinity area mainly near the Atlantic Ocean, may suggest the hypothesis of marine water intrusion. The high salinity can be explained also by the impact of evaporitic formations widely abundant in the Triassic and Jurassic formations.

\subsection{Process of Mineralization}

To indicate the influence of seawater intrusion on the salinity, the molar ratios $\mathrm{SO}_{4}^{2-} / \mathrm{Cl}^{-}$and $\mathrm{Mg}^{2+} / \mathrm{Ca}^{2+}$ vs $\mathrm{Cl}-$ are used (Figure 9). The report $\mathrm{SO}_{4}^{2-} / \mathrm{Cl}^{-}$(in meq/l) decreases when the proportion of seawater (represented by the tenor of chlorides in meq/l) increases in the mixture freshwater-seawater.

In the case where the origin is marine salt, the process of sulfate reduction should exist. The report $\mathrm{Mg}^{2+} / \mathrm{Ca}^{2+}$ increases with the proportion of sea water introduced into the mixture [18]. The highest values of the ratio $\mathrm{Mg}^{2+}$ / $\mathrm{Ca}^{2+}$ and the lowest values of the ratio $\mathrm{SO}_{4}^{2-} / \mathrm{Cl}^{-}$characterize the coastal waters of Siddi Akhfenir at the North indicating the marine waters.

The surface electrical resistivity tomography is a useful tool in determining seawater intrusion; for its capability to discriminate the large resistivity contrast between the presence of seawater and saturated fresh water layers. In the region of Chbieka (NW of basin Laayoun-Dakhla), where the anomaly of salinity exist, two tomographic profiles CBK1, CBK2, elongated NW-SE, has been made. These two profiles have similar electrical responses, and they show (Figure 10):

- A first resistant level with resistivity exceeding 67 $\mathrm{Ohm} \cdot \mathrm{m}$. It has a thickness of about $20 \mathrm{~m}$ and corresponds to a slab limestone, sandstones and conglomerates,

- A second highly conductive level with electrical resistivity below $5 \mathrm{Ohm} \cdot \mathrm{m}$ and has a thickness of about $60 \mathrm{~m}$. This level corresponds to fine sand marl, sand with gravel, and marl past compact blackish.

- The third resistant level with resistivity exceeding $12.8 \mathrm{Ohm} \cdot \mathrm{m}$ and being at a depth of about $90 \mathrm{~m}$. This level corresponds to the sandstone formation,

From the literature, salt water has a resistivity below $1.0 \mathrm{Ohm} \cdot \mathrm{m}$, in particular seawater has an average resistivity of $0.2 \mathrm{Ohm} \cdot \mathrm{m}$, while a layer saturated by saline water and dissolved solids has a resistivity in the range of 8 to $50 \mathrm{Ohm} \cdot \mathrm{m} \mathrm{[19]}$. Therefore, based on these values of resistivity data obtained in this work underscore the presence of strata saturated with brackish to saline water.

The first level, detected in the both tomographic profiles CBK1 and CBK2, is a resistant level (sandstone, limestone and sand) of Plio Quaternary overlying a con- 

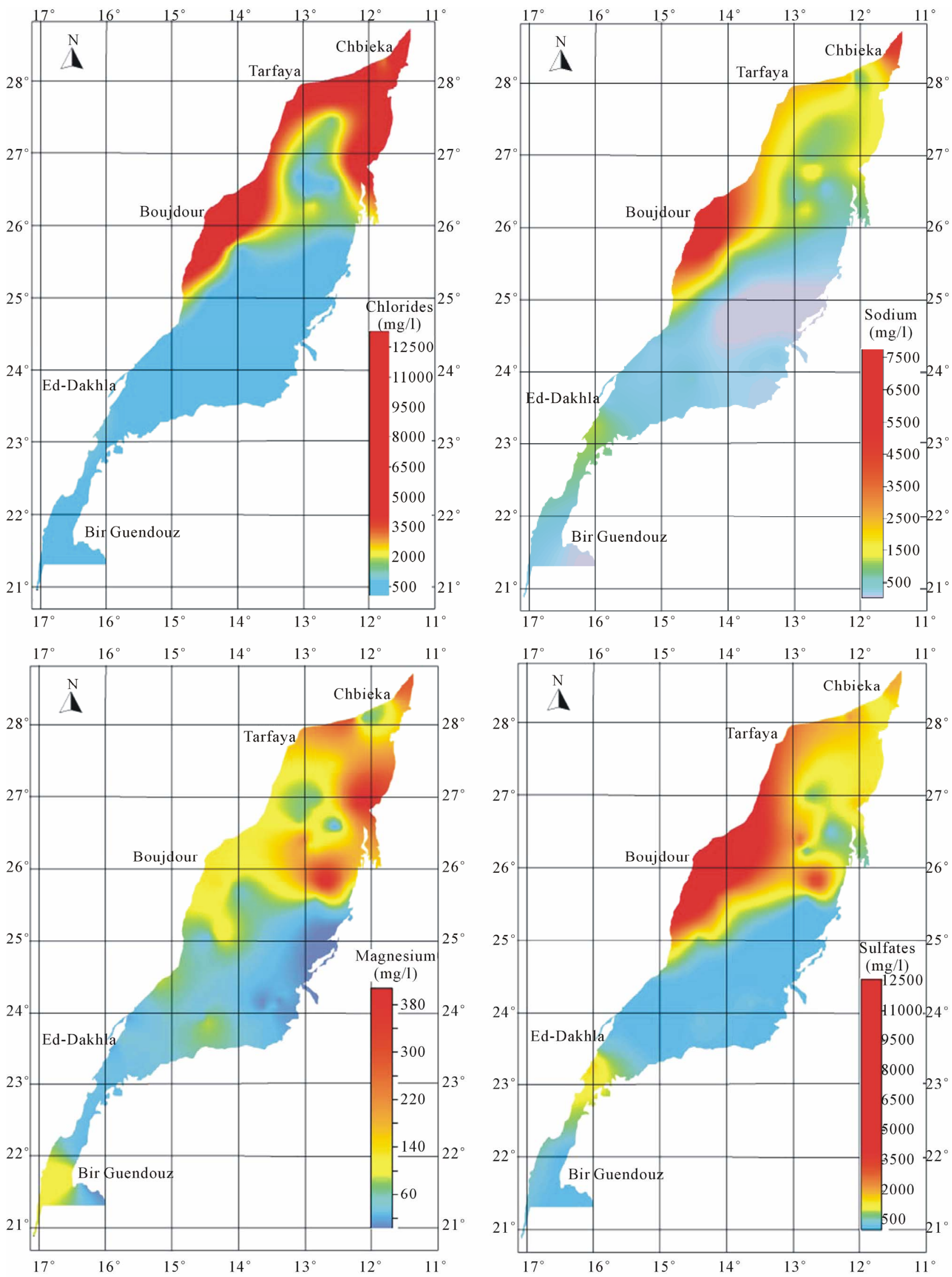

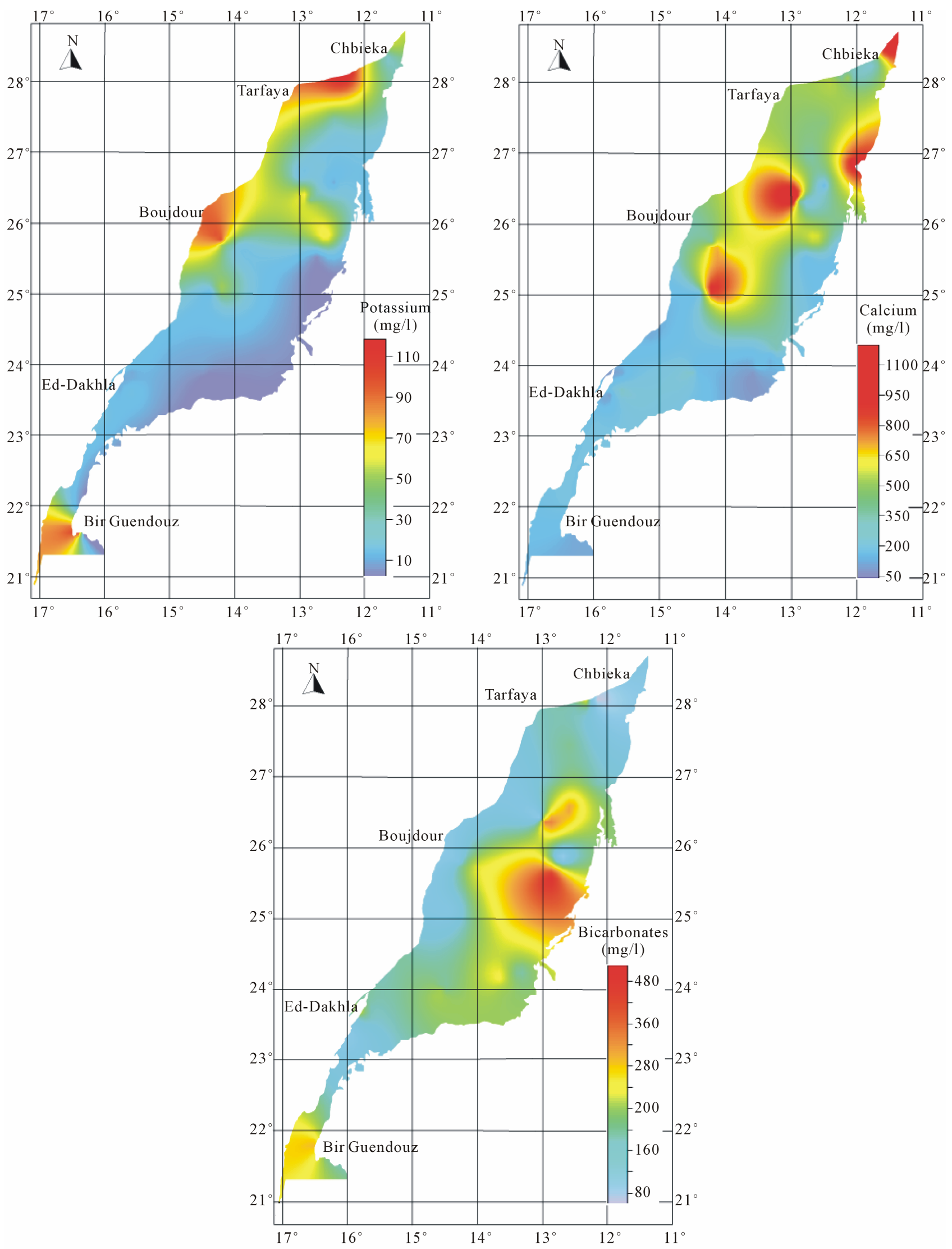

Figure 8. Spatial distribution map of major elements in the Laayoun-Ed Dakhla basin. 

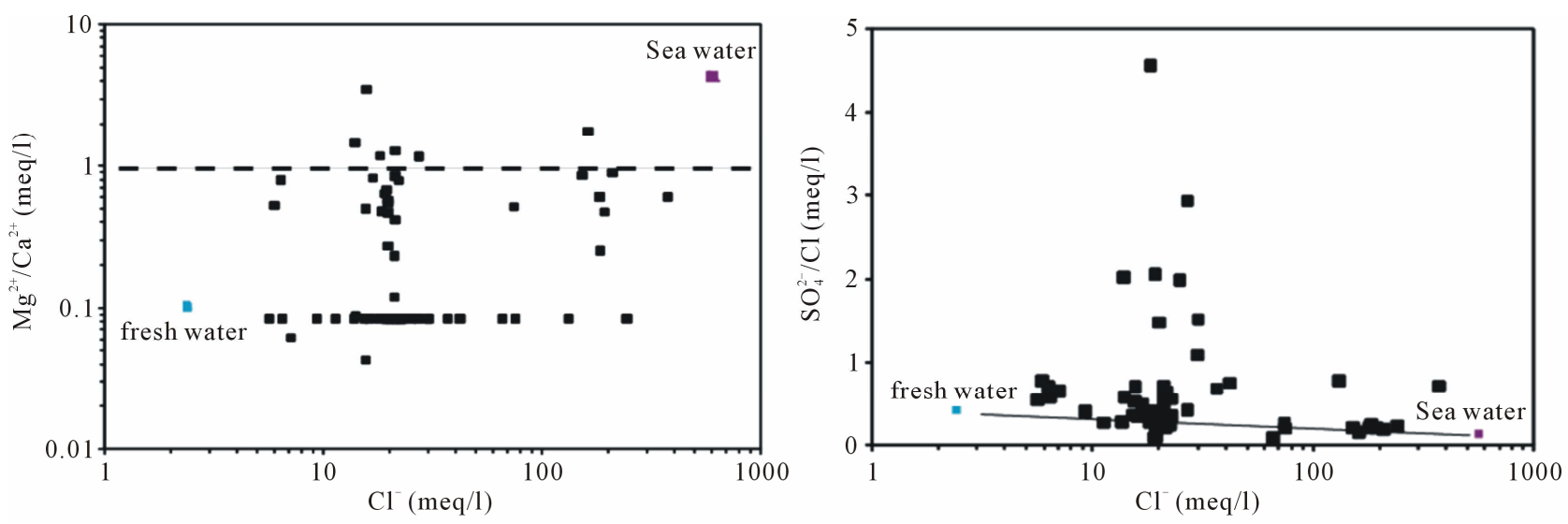

Figure 9. $\mathrm{SO}_{4}^{2-} / \mathrm{Cl}^{-}$and $\mathrm{Mg}^{2+} / \mathrm{Ca}^{2+}$ ratio (in meq/l) as a function of the $\mathrm{Cl}^{-}$content (meq/l) in the different samples.

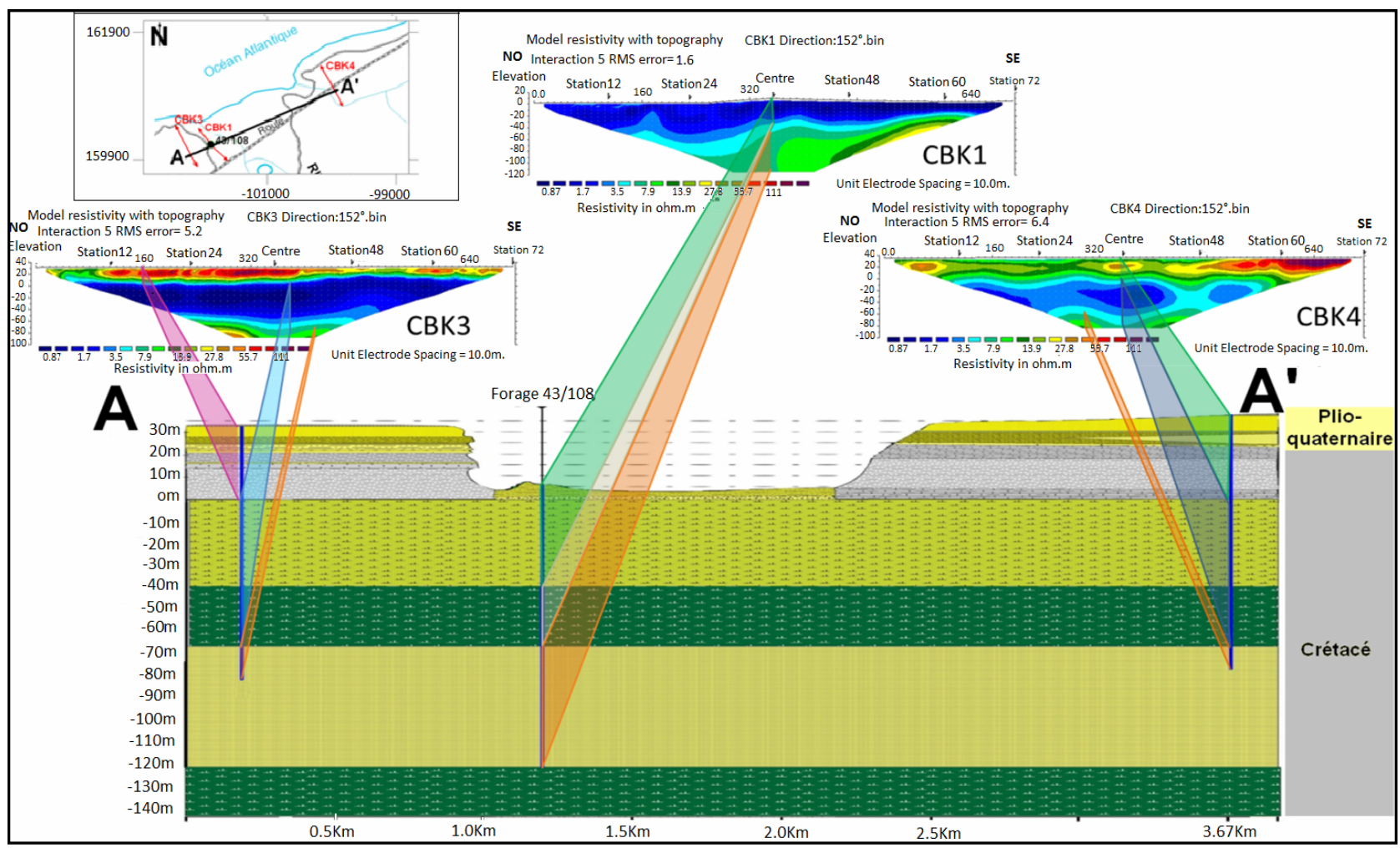

Figure 10. The different electrical levels detected by electrical tomography and Their correspondence lithological data from the coastal cliff sections of the data and the drilling of $43 / 108$.

ductive level (marl and clay). The both are greater than the sea level. On the second level, where there may be a seawater intrusion, is an impervious marly with thickness of about $60 \mathrm{~m}$. Marl is conductive formation which is reflected by low resistivity in the tomographic images; this level does not allow have a seawater intrusion in the LC aquifer. The third level is resistant (consolidated sandstones), the sand-stones have in general large resistivity) 30 to $800 \mathrm{Ohm} \cdot \mathrm{m}$ [20]. But in our case, the level resistant, corresponding to the sandstone, has low resistivity and important porosity contains salt water. No freshwater-saltwater interface was detected in the coastal aquifer.

The dissolution of evaporites is corroborated by the positive correlation between chloride and sodium, with a coefficient of $\left(\mathrm{R}^{2}=0.74\right)$, however, the molar concentration ratio $\mathrm{Na} / \mathrm{Cl}$ is often less than 1 (Figure 11).

The dissolution of these evaporites is confirmed by the saturation indices (SI) calculated. Indeed, the saturation indices of all waters towards the relevant minerals (gypsum and anhydrite) show an under-saturation for most samples (IS means towards the gypsum -0.62 , anhydrite 


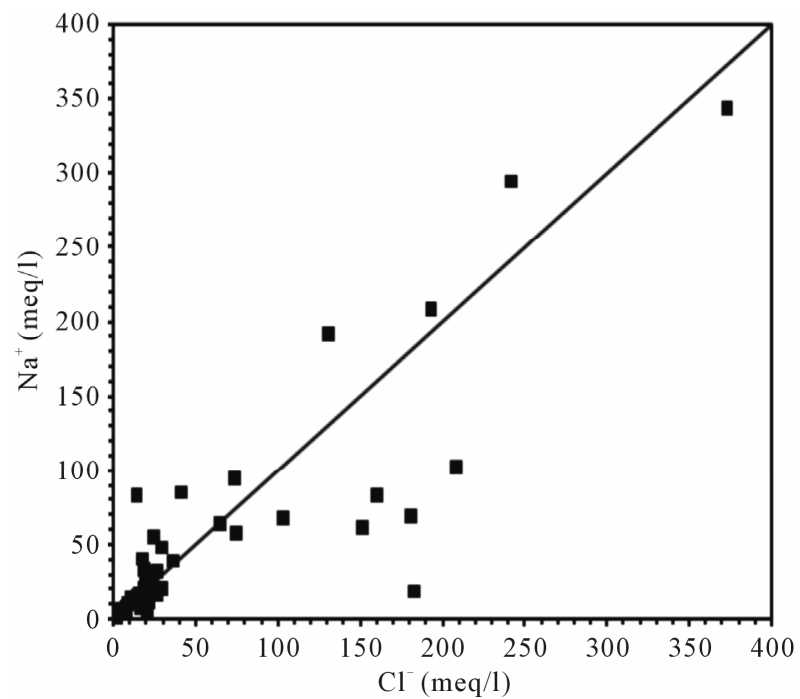

Figure 11. Relationships between $\mathrm{Cl}$ and $\mathrm{Na}$ in the analysed groundwater samples.
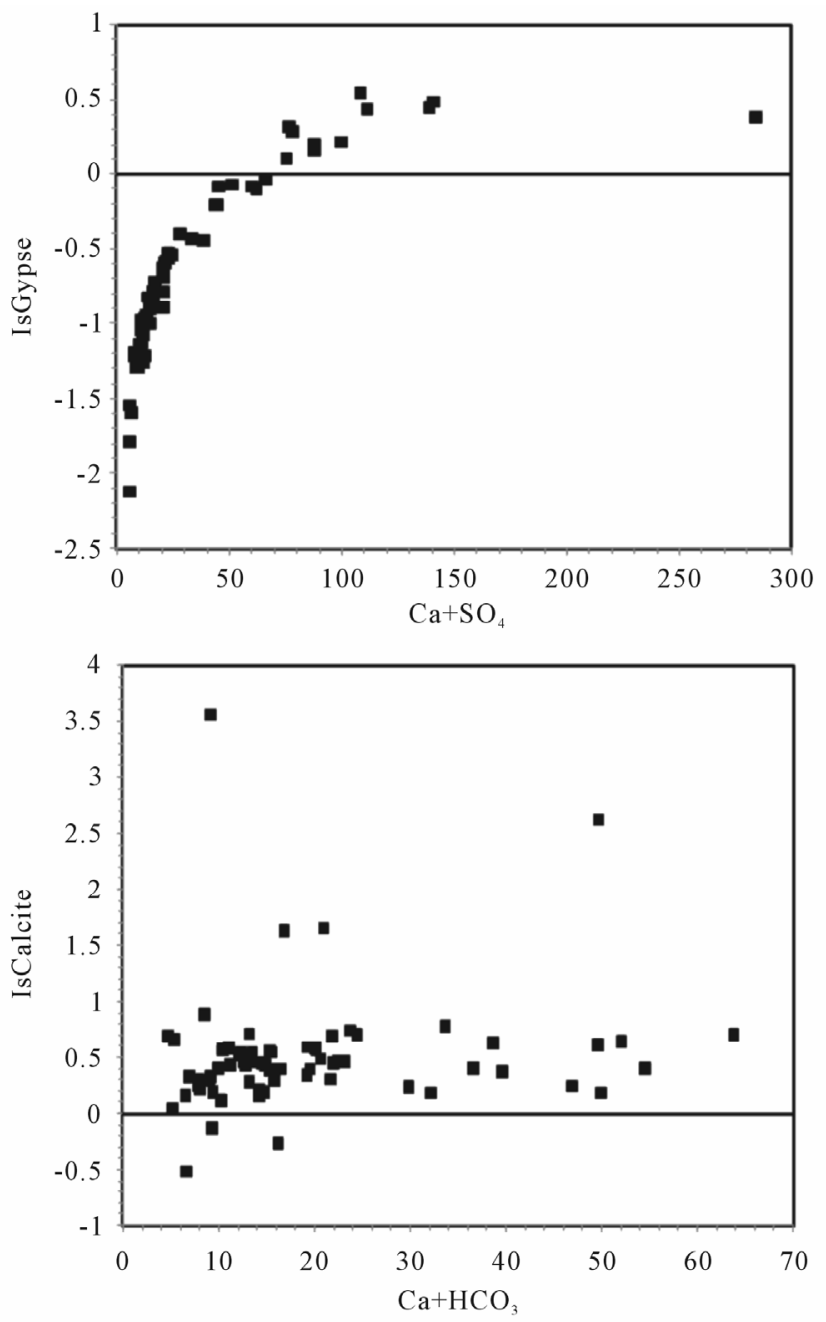

-0.84). Figure 12, illustrating the close correlation between the indices of water saturation towards the gypsum, as a function of $\mathrm{Ca}+\mathrm{SO}_{4}$, and anhydrite, according to $\mathrm{Na}$ $+\mathrm{Cl}$ respectively, support the hypothesis of evaporites dissolution. Many points are positioned below the right of gypsum dissolution reflecting a "deficit" in which $\mathrm{Ca}^{2+}$ can be attributed to a secondary precipitation of calcite. However, the absence of correlations between the water saturation indices towards the calcite as a function of $\mathrm{Ca}+\mathrm{HCO}_{3}$ (Figure 12) and dolomite as a function of $\mathrm{Ca}+\mathrm{Mg}+\mathrm{HCO}_{3}$ (Figure 12) indicates the dissolution of carbonate minerals.

The diagram of Gibbs [21] shows the evolution of the global salinity (TDS) versus $(\mathrm{Na} / \mathrm{Na}+\mathrm{Ca}$ ) for the waters of the aquifer. Such scheme allows the distinction between the waters controlled by evaporation and those influenced by a process of water-rock interaction [22,23]. It indicates that the waters are grouped into the evaporation area (Figure 13).
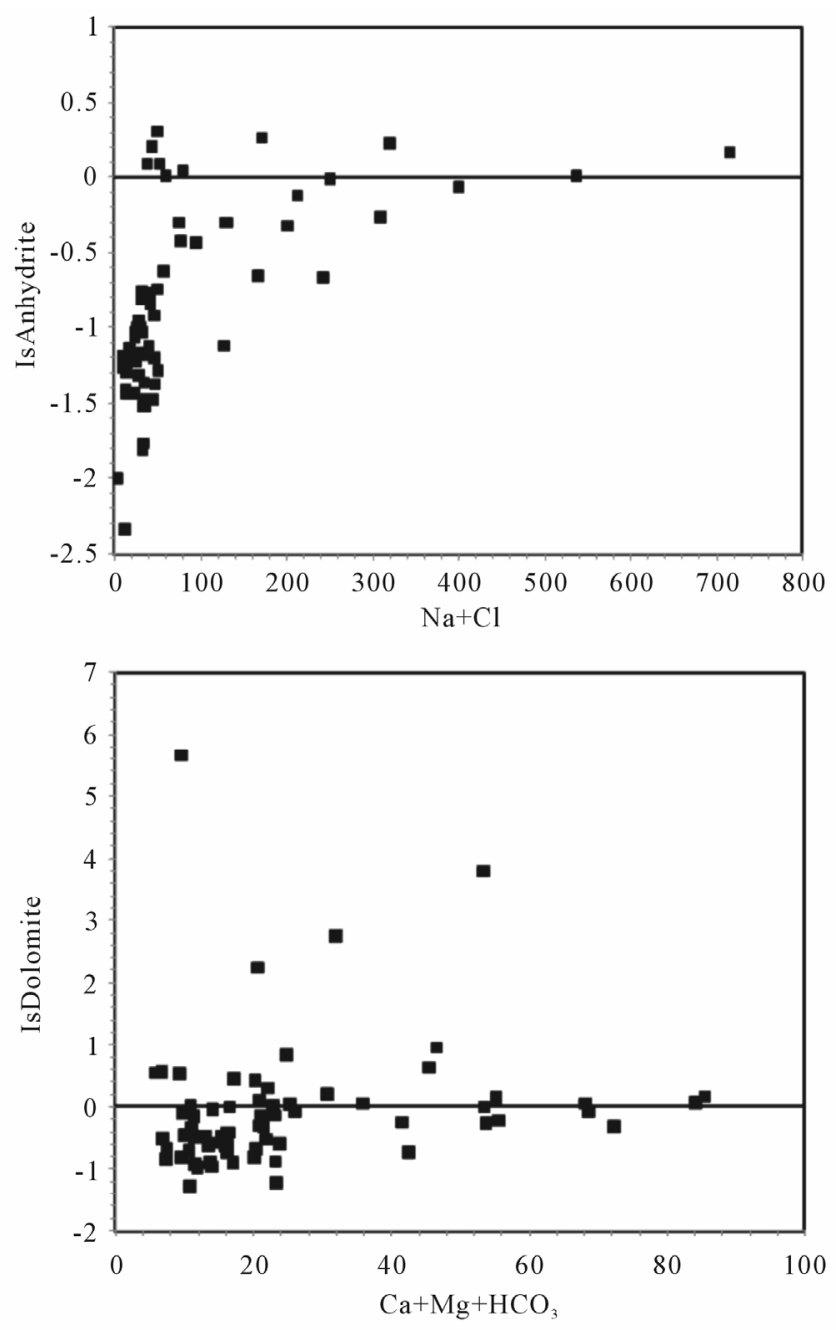

Figure 12. Saturation indices of gypsum, anhydrite, calcite and dolomite versus $\left(\mathrm{Ca}+\mathrm{SO}_{4}\right),(\mathrm{Na}+\mathrm{Cl}),(\mathrm{Ca}+\mathrm{HCO})$ and $(\mathrm{Ca}+$ $\mathrm{HCO}_{3}+\mathrm{Mg}$ ), respectively. 


\section{$\operatorname{TDS}(\mathrm{mg} / \mathrm{l})$}

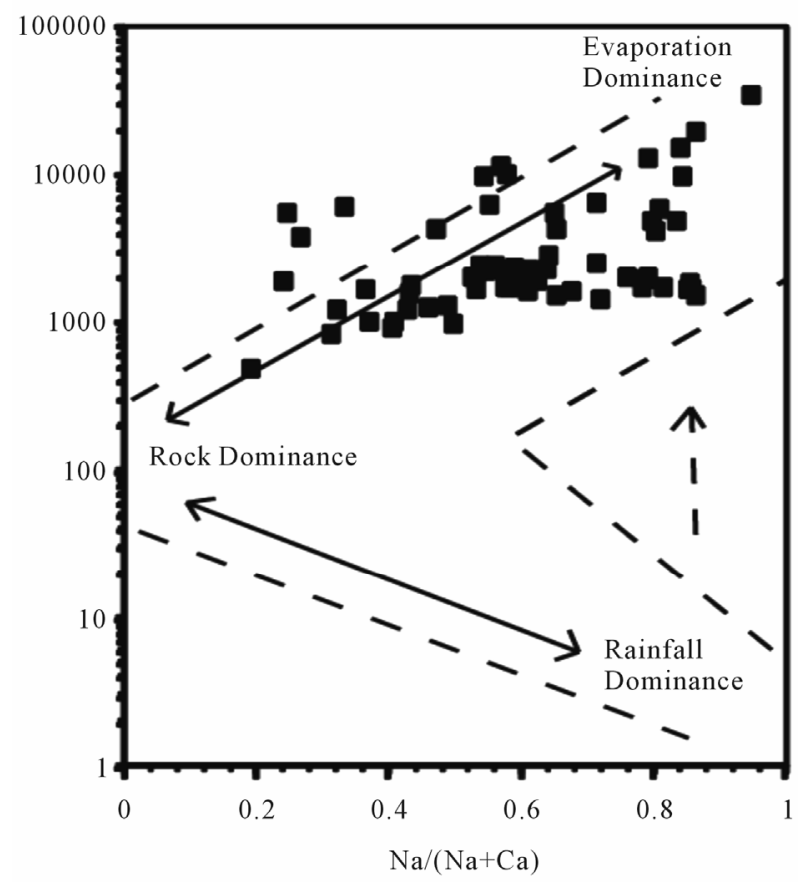

Figure 13. Groundwater of the LC aquifer plotted on the Gibbs diagrams.

\subsection{Discussion about the Origin of the Salinity in LC Groundwater}

During the drift phase (Jurassic to Recent) several abrupt changes in drift direction occurred which affected the African plate [14]. The first offshore sedimentation is marked by the deposition of Triassic red bed (Brown, 1980), followed by Early Jurassic salt in the late rifting phase. Up to $5000 \mathrm{~m}$ of red marine to fluvial clastics were deposited in the onshore south Moroccan Basins $[16,24,25]$, and seismic evidence indicates the Triassic sequence has a similar thickness in the offshore region $[25,26]$. The thickest salt along the NW African margin is located in the deepest half-graben formed during the rifting (Figure 14). Downslope sliding of overburden above the salt is limited to within individual fault blocks due unequal nature of the salt $[27,28]$. Synrift deposits have been penetrated in several wells in the central onshore Laayoune-Tarfaya Basin. These are conglomerates, red shales and sandstones, evaporites and volcanics [29]. Triasic and Lower to Middle Jurassic strata are only present in the northern part of the basin near Tarfaya, Salt has been previously indicated between Dakhla and Boudjour [24,30]. However, [31] have also suggested that mud diapirs are present. The existence of deep salt

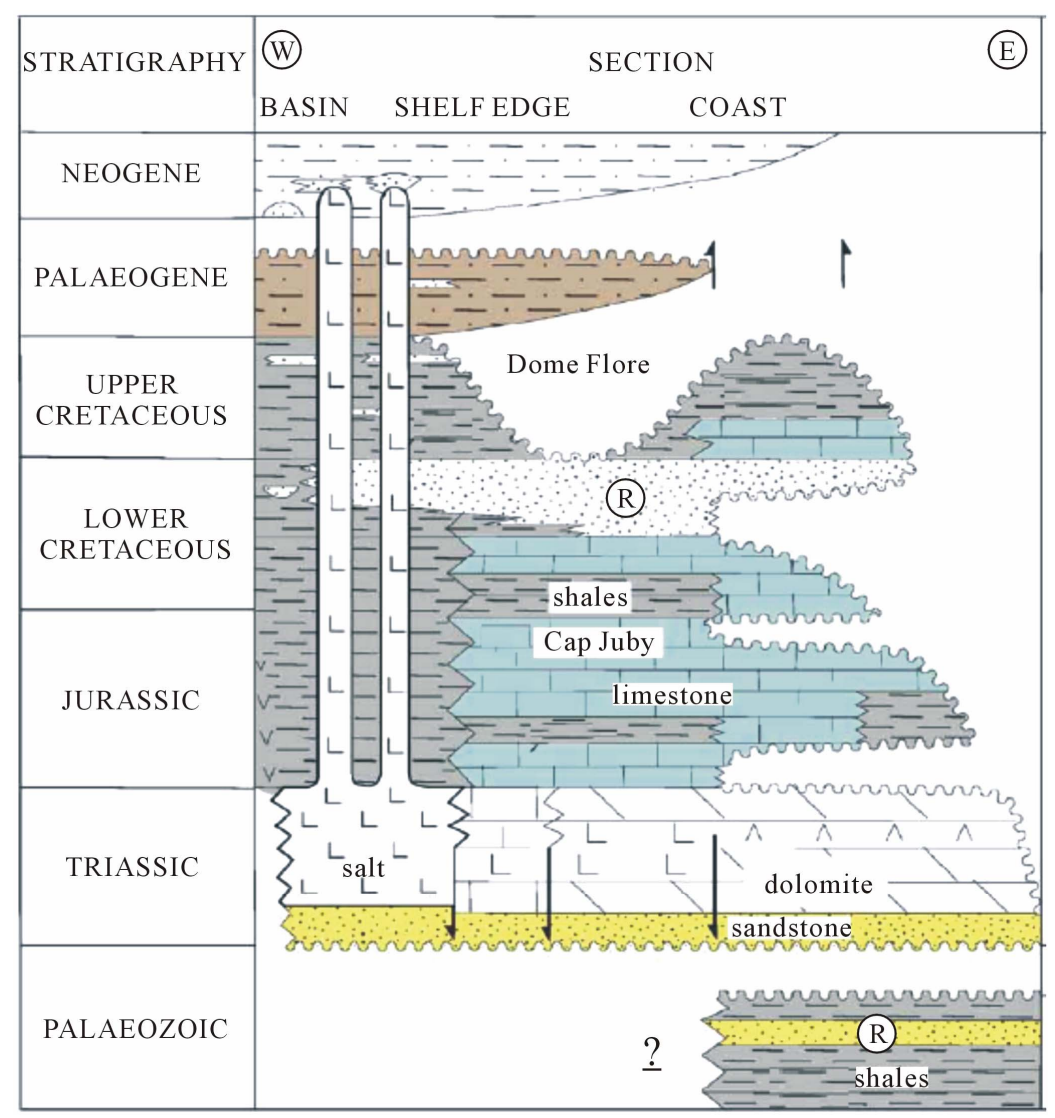

Figure 14. Summary diagrams showing the common stratigraphic and tectonic features which are present along most of the NW African margin [12]. 
water rising in the north, outcome from evaporitic formations of Trias and gypsiferous Jurassic, increases the mineralization of water. By cons in the south, the water in contact with the granite of the primary are less loaded and evolves from a bicarbonate-sodium facies in the east to a chloride- sodium facies to the west (Figure 15).

\section{Isotopes of Water Molecule (18O/2H)}

In arid environments, the recharges of the large sedimentary aquifers by network surface waters are extremely limited or nonexistent [33]. Transfers of water between aquifers are difficult revealed by "traditional" methods of hydrogeology. However, this phenomenon has often been highlighted by the study of environmental isotopes [1,2,34-38]. For this study, 33 groundwater samples were selected for $\delta 18 \mathrm{O}, \delta 2 \mathrm{H}$ and $\delta 3 \mathrm{H}$ measurements are performed by the National Energy Center and Nuclear Science and Technology.

\section{Discussion and Results}

The results of the analyses of the tritium in LC waters show a variation in concentration between 0.12 and 0.13 UT. It indicates that we are in the presence of older waters that formed in wetter periods than the current. The presence of tritium in groundwater, witness the recent addition of water, does not automatically translate an effective recharging. Conversely, the absence of tritium does not necessarily mean an absence of current recharging; it may simply be a transit time of water in the unsaturated zone.

The values obtained of 180 expressed in \%o ranges from -8.93 to -6.96 with an average of -8.37 for the water of the LC aquifer. The deuterium content varies between -64.10 and $-51.5 \%$ with an average of -61.47 . Indeed, in the diagram $18 \mathrm{O}$ vs $2 \mathrm{H}$ (Figure 16), the points representing the waters of the LC are situated below the meteoric water line global precipitation except tow points (wells $\mathrm{N}^{\circ} 46$ and $\mathrm{N}^{\circ} 64$ ) which lie on this line. Water samples from these wells were collected in the Boucraa re- gion and Bir Guendouz. Their stable isotope composition suggests the presence of an admixture of recently recharged water. Position of other samples representing LC indicates their recharge was carried out under cooler paleoclimatic conditions than the current.

The graph $18 \mathrm{O}$ vs. $\mathrm{Cl}^{-}$(Figure 17) shows that the levels of 180 remain relatively constant whatever the chloride contents varying between 5.6 and $242 \mathrm{meq} / \mathrm{L}$. This relationship allows us to reject the hypothesis of a mixture between freshwater and seawater since all points are located far from the "sea pole" and the mixing line $((\mathrm{Cl}$ " $=560$ meq 1" $1 ; 180=+0.88 \%$ vs V-SMOW, [39].

In large aquifers, the spatial homogenization of the isotopic composition of groundwater often reflects a prolonged residence time, allowing mixing processes and diffusion to delete all traces of possible variations due to successive recharging episodes [40], which the "age" can be confirmed by carbon-14 dating.

Activities $14 \mathrm{C}$ measured dissolved inorganic carbon in water samples ranged from 0.3 to $63.8 \mathrm{pcm}$ (percent modern carbon). In the diagram $18 \mathrm{O}$ vs $14 \mathrm{C}$ (Figure 18), the range of PMC ( 0 - 8) deep groundwater recharge corresponds with late Pleistocene, although there then follows a hiatus in the data, with no results in the range 10 20 PMC. This hiatus has been interpreted in data from across the Sahara as a gap in the recharge conditions coincident with the last glacial maximum when hyperarid but cool conditions extended over the Sahara [41,42]. Values exceeding 16.5 de14C PCM represent recharge during the Holocene, possibly related to the northward extension of monsoon rains from the south [43].

It is apparent from the limited $14 \mathrm{C}$ data that waters of Holocene age are found in the profile to a distance of some $\mathrm{km}$ from Oum draigua and Bir Anzaran outcrop (located east of the basin), and Lamsid in the west of the basin, they are isotopically enriched ( $\mathrm{d} 18 \mathrm{O}$ values around $-7 \%$ ), in contrast with most waters in the late Pleistocene which have lighter compositions ( $\mathrm{d} 18 \mathrm{O}$ around $-8 \%$ ). Some anomalies are likely to be due to mixing of shallow and deep waters, but it is unlikely that upward

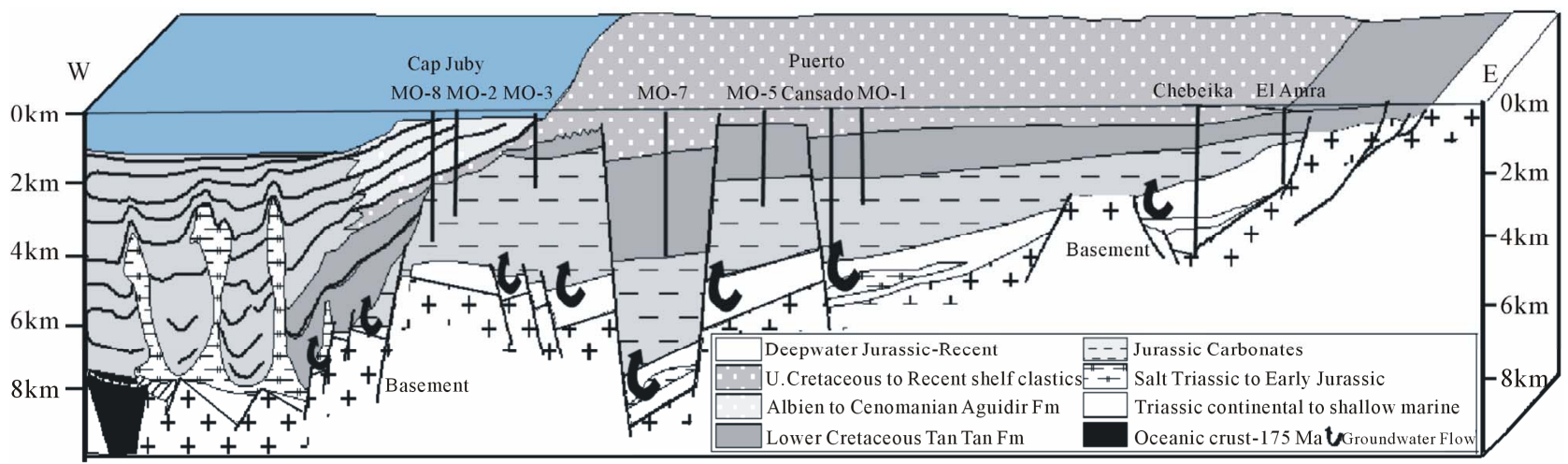

Figure 15. Schematic cross section of the Tarfaya Basin extrapolated out to Fuertaventura. Based on section in ONAREP [12]. 


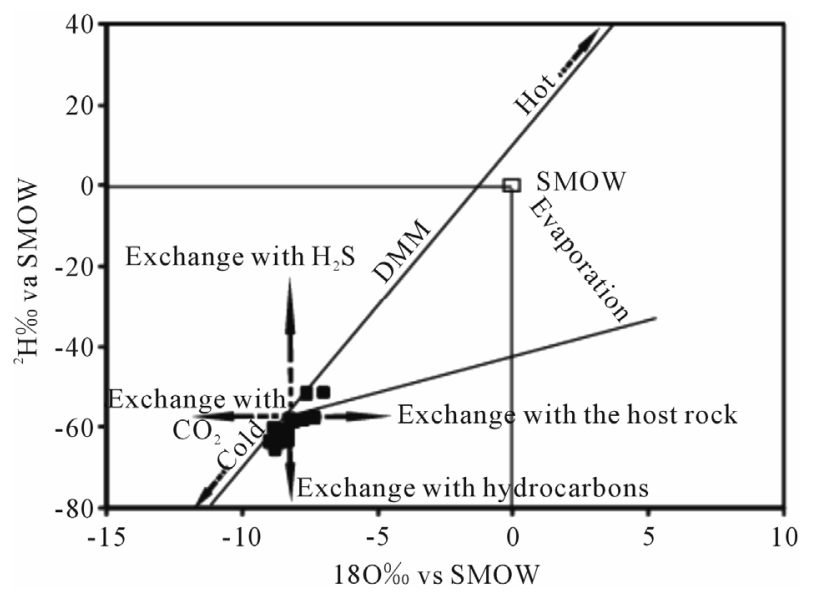

Figure 16. Stable isotope composition of LC groundwaters.

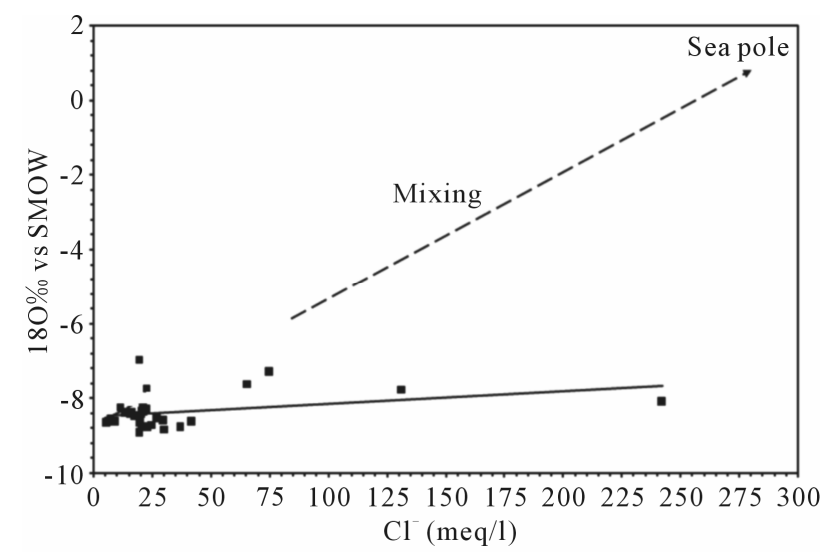

Figure 17. Correlation between 180 vs SMOW and $\mathrm{Cl}^{-}$.

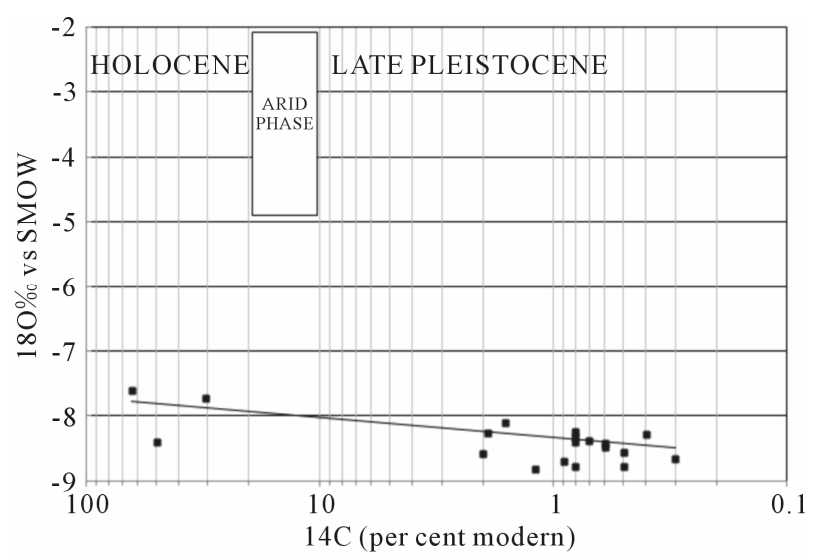

Figure 18. Plot of d180 against 14C (pmc) for all groundwaters for which age information is available.

leakage from the deep aquifer is unimportant.

\section{Conclusions}

The analysis of physico-chemical parameters in the laayoune-Dakhla basin showed a large spatial variation of mineralization from north to south and an increasing evolution of mineralization to the west is disturbed in the northern zone of the basin.

Two hypotheses are discus relating to the origin of this salinity; it can come from: 1) a marine intrusion in the NW part of the basin or 2) an impact of evaporitic formations in the basin. The use of geo-electrical method combined with the chemical analysis show that the principal changes in chemical composition of groundwater result from mixing with Triassic and Jurassic water of deeper circulation in the North of the basin.

The mineralization is controlled also by fault essentially in the north part of the basin, although, in the south part the absence of the Triasic and Jurassic formation suggest the mineralization is controlled by granitic formation.

Overlap of some major characteristics $\left(\delta 18 \mathrm{O}, \delta 2 \mathrm{H}, \mathrm{Cl}^{-}\right)$ in this aquifer indicates that the recharge was carried out under conditions paleoclimatic cooder than the current. It is essentially recharged water from the same altitude. The mixing processes considerably influence the hydro-chemical evolution of water.

The surface electrical resistivity tomography showed any freshwater-saltwater interface in the coastal aquifer.

\section{Acknowledgements}

The authors thank the members of the Hydraulic Basin Agency Sakia El Hamra and Oued Ed-Dahab, Mr Rachid Ghandi and Abdelhak Sadiki, for their collaboration and for documents that are available to us. The author would also like to express their appreciation to M Mouhammed Chibout and mustapha chakir from Africa Geo_office services.

\section{REFERENCES}

[1] R. Gonfiantini, G. Conrad, J.-Ch. Fontes, G. Sauzay and B. R. Payne, "Étude Isotopique de la Nappe du Continental Intercalaire et Ses Relations Avec Les Autres Nappes du Sahara Septentrional," Proceedings of IAEA Symposium on Isotope Techniques in Groundwater Hydrology, Vienna, 11-15 March 1974, pp. 227-241.

[2] J. C. Fontes and R. Gonfiantini, "Isotopic Behavior during Evaporation of Two Saharan Basins," Earth and Planetary Science Letters, Vol. 3, 1967, pp. 258-266.

[3] Hydraulic Basin Agency, S. El Hamra and O. Ed-Dahab, "Study of the Master Plan Integrates Water Resources Mission II: Assessment of Water Needs and Potential Uses of Water Resources and Aquatic Ecosystems (Pdaire)," Repart 08/2007

[4] A. Guendouz, A. S. Moulla, W. M. Edmunds, K. Zouar, P. Shand and A. Mamou, "Hydrogeochemical and Isotopic evolution of Water in the Complexe Terminal Aquifer in the Algerian Sahara," Hydrogeology Journal, Vol. 11, No. 4, 2003, pp. 483-495.

[5] S. Boutaleb, L. Bouchaou, Y. Hsissou, J. Mudry, J. Mania 
and P. Chauve, "Hydrogeologic Effects on the Quality of Water in the Oued Issen Watershed, Western Upper Atlas Mountains, Morocco," Hydrogeology Journal, Vol. 8, No. 2, 2000, pp. 230-238. doi:10.1007/s100400050009

[6] Y. Nazoumou and M. Besbes, "Estimation of Recharge and Groundwater Modeling in Arid Zone: The Case of the Sheet of Kairouan, Tunisia," Proceedings of a Symposium Held during the Sixth IAHS Scientific Assembly, Maastricht, July 2001.

[7] N. Al Farrah, K. Martens and K. Walraevens, "Hydrochemistry of the Upper Miocene-Pliocene Quaternary Aquifer Complex of Jifarah Plain, NW-Libya," Geologica Belgica, Vol. 14, No. 3-4, 2011, pp. 159-174.

[8] A. M. Sharaky, S. A. Atta, A. S. El hassanein and K. M. A Khallaf, "Hydrogeochemistry of Groundwater in the Western Nile Delta Aquifers, Egypt," 2nd International Conference on the Geology of Tethys, Cairo, 19-21 March 2007.

[9] G. Choubert, "Histoire Géologique du Domaine de L'Anti Atlas," Note et Mémoire Service Géologique Maroc, Vol. 100, 1952, pp. 75-194.

[10] A. Michard, "Elements of Geology Morocco, Notes and Memories, Geological Survey of Morocco," Vol. 252, 1976, pp. 1-420,

[11] Quirol, "Regional Geology of the Moroccan Sahara," Bureau de Recherche et de Participations Minières, 1976.

[12] I. Davison, "Central Atlantic Margin Basins of North West Africa: Geology and Hydrocarbon Potential (Morocco to Guinea)," Journal of African Earth Sciences, 2005.

[13] A. M. Morabet, R. Bouchta and H. Jabour, "An Overview of the Petroleum Systems of Morocco," In: D. S. Macgregor, R. T. J. Moody and D. D. Clark-Lowes, Eds., Petroleum Geology of North Africa, Geological Society of London Special Publication, 1998, pp. 283-296.

[14] M. A. Heyman, "Tectonic and Depositional History of the Moroccan Continental Margin," In: A. Tankard and H. Balkwill, Eds., Extensional Tectonics and Stratigraphy of the North Atlantic Margin, AAPG Memoir 46, 1989, pp. 323-340.

[15] L. Kouzana, "Intrusion Marine et Salinisation des Eaux D'une Nappe Phréatique Côtière (Korba, Cap-Bon, Tunisie)", Geo-Eco-Trop, Vol. 31, 2007, pp. 57-70

[16] A. Satriani, A. Loperte and M. Proto, "Electrical Resistivity Tomography for Coastal Salt Water Intrusion Characterization along the Ionian Coast of Basilicata Region (Southern Italy)," International Water Technology Journal, Vol. 1, No. 1, 2011.

[17] D. Chapellier and J. L. Mari, "Cours Online de la Géophysique de l'Université de Lausanne-Principes de Base," 2007.

[18] R. J. Gibbs, "Mechanisms Controlling Worlds Water Chemistry," Science, Vol. 170, 1971, pp. 1088-1090.

[19] S. Ettazarini, "Processes of Water-Rock Interaction in the Turonian Aquifer of Oum Er-Rabia Basin, Morocco," Environmental Geology, Vol. 49, No. 2, 2005, pp. 293299.

[20] K. Srinivasamoorthy, S. Chidambaram, M. V. Prasanna,
M. J. P. Vasanthavihar and P. Anandhan, "Identification of Major Sources Controlling Groundwater Chemistry from a Hard Rock Terrain: A Case Study from Mettur Taluk, Salem District, Tamil Nadu, India," Journal of Earth System Science, Vol. 117, No. 1, 2008, pp. 49-58.

[21] R. H. Brown, "Triassic Rocks of the Argana Valley, Southern Morocco, and Their Regional Structural Implications," Bulletin American Association of Petroleum Geologists, Vol. 64, 1980, pp. 988-1003.

[22] P. Le Roy and A. Pique, "Triassic-Liassic Western Moroccan synrift Basins in Relation to the Central Atlantic Opening," Marine Geology, Vol. 172, No. 3-4, 2001, pp. 359-381. doi:10.1016/S0025-3227(00)00130-4

[23] P. Le Roy, A. Pique, B. Le Gall, L. Ait Brahim, Al M. Morabet and A. Denati, "Coastal Basins Triassic-Liassic of Morocco and Western Intracontinental Rifting of the Diachrony of the Central Atlantic," Bulletin de la Société Géologique de France, Vol. 168, 1997, pp. 637-648.

[24] G. Tari, J. Molnar, P. Ashton and R. Hedley, "Salt Tectonics in the Atlantic Margin of Morocco," The Leading Edge, Vol. 19, No. 10, 2000, pp. 1074-1078. doi:10.1190/1.1438481

[25] G. Tari, J. Molnar, P. Ashton and R. Hedley, "Examples of Salt Tectonics from West Africa: A Comparative Approach," In: T. Arthur, D. S. MacGregor and N. R. Cameron, Eds., Petroleum Geology of Africa: New Themes and Developing Technologies, Geological Society London Special Publications, 2003, pp. 131-150.

[26] U. Ranke, U. Von Raad and G. Wissmann, "Stratigraphy, Facies, and Tectonic Development of On- and Offshore Aaiun-Tarfaya Basin a Review," In: U. Von Raad, Ed., Geology of the North West African Continental Margin, Springer-Verlag, Berlin, 1982, pp. 86-104. doi:10.1007/978-3-642-68409-8 6

[27] E. K. Uchupi, K. O. Emery, C. O. Bowin, et al., "Continental Margin off Western Africa from Senegal to Portugal," Bulletin American Association of Petroleum Geologists, Vol. 60, 1976, pp. 809-878.

[28] U. Von Rad and G. Wissmann, "Cretaceous-Cenozoic History of the West Saharan Continental Margin (NW Africa): Development, Destruction and Gravitational Sedimentation in Geology of NW Africa," In: U. Von Raad, Ed., Geology of the North West African Continental Margin, Springer-Verlag, Berlin, 1982, pp. 106-129.

[29] ONAREP, "Opportunities for Hydrocarbon Exploration and Production in Morocco," Publicity Brochure, Morroco, 2003.

[30] J. F. Aranyossy, "The Contribution of Isotope Techniques to Study the Recharge under Constraints Techniques and Climate Extremes," Diploma for Accreditation to Supervise Research in Sciences, Univ. Paris-Sud (Orsay), 1991, p. 576.

[31] J. N. Andrews, J.-Ch. Fontes, J. F. Aranyossy, A. Dodo, W. M. Edmunds, A. Joseph and Y. Travi, "The Evolution of Alkaline Groundwaters in the Continental Intercalaire Aquifer of the Irhazer Plain, Niger," Water Resources Research, Vol. 30, No. 1, 1994, pp. 45-61. doi:10.1029/93WR02226

[32] J. Tóth, "Groundwater as a Geologic Agent: An Overview 
of the Causes, Processes, and Manifestations," Hydrogeology Journal, Vol. 7, 1999, pp. 1-14.

[33] A. El Achheb, J. Mania and J. Mudry, "Mechanisms Acquisitions Mineralization of Groundwater in the BasinDoukkala Sahel (Western Morocco) Approach Hydrogeochemical Tracers," Madrid, 2003.

[34] M. Bahir, P. Carreira, M. Oliveira da Silva and P. Fernandes, "Hydrodynamical, Hydrochemical and Isotopic Characterizationc of the Kourimat Aquifer System (Essaouira basin, Morocco)," Estudios Geologicos, 2008.

[35] S. Boutaleb, L. Bouchaou, Y. Hsissou and T. Tagma, "Determining the Terms of Recharge through Chemical and Isotopic Tracers: Case of the Contact Area Western High Atlas-Souss Plain (SW Morocco)," Estudios Geológicos, Vol. 64, No. 1, 2008.

[36] A. Marjoua, "Origins of salts in the aquifer of the coastal Chaouia (Morocco)," Proceedings of the Rabat Symposium, April 1997.

[37] J. F. Aranyossy, R. Njitchoua and Zuppi, "The Contri- bution of Environmental Isotopes to Study Recharge and Aquifer Dynamics,'In: C. Causse and F. Gasse, Eds., Hydrologie et Géochimie Isotopique. ORSTOM, Paris, 1998, pp. 39-54.

[38] A. Guendouz, et al., "Hydrochemical and Isotopic Behaviour of a Saharan Phreatic Aquifer Suffering Severe Natural and Anthropic Constraints (Case of Oued-Souf Region, Algeria)," Hydrogeology Journal, Vol. 14, No. 6, 2005, pp. 955-968.

[39] S. Kamel, L. Dassi and K. Zouari, "Approche Hydrogéologique et Hydrochimique des éChanges Hydrodynamiques Entre Aquifères Profond et Superficiel du Bassin du Djérid, Tunisie," Hydrological Sciences Journal, Vol. 15, No. 4, 2010, pp. 713-730.

[40] Y. Hamed, L. Dassi, R. Ahmadi and H. Ben Dhia, "Geochemical and Isotopic Study of the Multilayer Aquifer System in the Moulares-Redayef Basin, Southern Tunisia," Hydrological Sciences Journal, Vol. 53, No. 6, 2010. 